Article

\title{
Ultrasound Assisted Extraction of Phenolic Compounds from a Jujube By-Product with Valuable Bioactivities
}

\author{
Farida Berkani ${ }^{1}$, Maria Luisa Serralheiro ${ }^{2,3, *(D)}$, Farid Dahmoune ${ }^{4,5}$, Asma Ressaissi ${ }^{2}$, \\ Nabil Kadri ${ }^{4,5}$ and Hocine Remini 4,5 (D) \\ 1 Laboratory of Management and Valorization of Natural Resources and Quality Assurance (LGVRNAQ), \\ Faculty of Nature and Life Sciences and Earth Sciences, University of Bouira, Bouira 10000, Algeria; \\ f.berkani@univ-bouira.dz \\ 2 Faculty of Sciences, BioISI-Biosystems \& Integrative Sciences Institue, University of Lisbon, \\ 1649-004 Lisboa, Portugal; aressaissi@fc.ul.pt \\ 3 Faculty of Sciences, Departamento de Quimica e Bioquimica, University of Lisbon, Campo Grande, \\ 1749-016 Lisboa, Portugal \\ 4 Department of Biology, Faculty of Natural and Life Sciences and Earth Sciences, University of Bouira, \\ Bouira 10000, Algeria; f.dahmoune@univ-bouira.dz (F.D.); kadri.mont2@gmail.com (N.K.); \\ hocine_r06@live.fr (H.R.) \\ 5 Laboratory of Biomathematics, Biophysics, Biochemistry, and Scientometry (L3BS), \\ Faculty of Nature and Life Sciences, University of Béjaia, Béjaia 06000, Algeria \\ * Correspondence: mlserralheiro@fc.ul.pt
}

Received: 13 October 2020; Accepted: 9 November 2020; Published: 11 November 2020

\begin{abstract}
Jujube plant is a potential source of polyphenols with biological propreties. The purpose of this study was to investigate the application of ultrasound technique for extracting phenolic compounds (TPC) from seeds of Zizyphus lotus under optimization conditions based on response surface methodology. A maximum TPC, total flavonoids content (TFC), and total condensed tannins content (TTC) of $2383.10 \pm 0.87 \mathrm{mg} \mathrm{GAE} / 100 \mathrm{~g}, 486.50 \pm 0.38 \mathrm{mg} \mathrm{QE} / 100 \mathrm{~g}$ and $15,787.10 \pm 0.10 \mathrm{mg} \mathrm{CE} / 100 \mathrm{~g}$, respectively obtained under ethanol concentration $50.16 \%$, sonication temperature $29.01{ }^{\circ} \mathrm{C}$, sonication time $15.94 \mathrm{~min}$ and solvent-to-solid ratio $34.10: 1 \mathrm{~mL} / \mathrm{g}$. The optimized extract was then evaluated for its antioxidant, antiacethylcholinesterase, antihypercholesterolemia, and antiproliferative activities. The results showed that ultrasound method is a green and safe method that can be used to effectively extract TPC from jujube seeds. The biological activity of Zizyphus extract exhibited a very good antioxidant against DPPH $\left(\mathrm{EC}_{50}=0.39 \mu \mathrm{g} / \mathrm{mL}\right)$ and FRAP $(1670.42 \pm 6.5 \mathrm{mg} / 100 \mathrm{~g})$. Additionally, it possesses acetylcholinesterase (AChE) inhibitory effect $\left(\mathrm{IC}_{50}=0.93 \pm 0.01 \mathrm{mg} / \mathrm{mL}\right)$ and HMGR inhibition (45.41\%) using $100 \mu \mathrm{g} / \mathrm{mL}$. The extract significantly inhibits cell proliferation on the MCF-7 and $\mathrm{HepG}_{2}$ tumor cell lines with an $\mathrm{IC}_{50}$ values of $<0.05$ and $3 \pm 0.55 \mathrm{mg} / \mathrm{mL}$, respectively. Therefore, the ultrasound method can be considered a method for obtaining a significant anticancer activity with respect to the lines and therefore makes it possible to recover a maximum of phenolic compounds in less time with an AChE and HMGR inhibitory activity. Thus, it can be suggested that Zls extract is a promising fruit for the development of supplementary dietary due to its potential behaviour as nutraceutical.
\end{abstract}

Keywords: jujube; ultrasound; response surface methodology; polyphenols; biological activities

\section{Introduction}

The production of free radicals (FR) is associated with many physiological and biochemical processes that have taken place in the human body and their over production leads to the appearance of 
many cardiovascular diseases which can cause significant oxidative damage to biomolecules, namely, lipids, proteins, or DNA [1]. Due to the release of FR such as the superoxide radical, the hydroxyl radical, hydrogen peroxide, and lipid peroxide radicals, antioxidants are capable to inhibit the oxidation of other molecules and preventing cell death. In contrast, several authors have shown that FR scavenging are associated with the mixture of nutrients consumed regularly by humans and have shown that a high intake of antioxidants results in the reduction of these diseases [2].

The alteration of cerebral cholinergic neurotransmission, more precisely the basal nucleus of Meynert which is deficient in cholinergic neurons are the main causes of progressive loss of attention and memory, in other words, Alzheimer's disease (AD) [3]. In the treatment of this disease acetylcholinesterase (AChE, E.C. 3.1.1.7) inhibition has been used [4]. AChE is an enzyme localized in the neurosynaptic gaps [5] and neuromuscular junctions [6]. As a result of this inhibition process the neurotransmitter acetylcholine remains in the neurosynaptic gap for a longer period of time, keeping the person having $\mathrm{AD}$ in a more active mental state [7-9].

The $\beta$-Hydroxy- $\beta$-methylglutaryl coenzyme A reductase (HMGR, E.C. 1.1.1.88), a rate-limiting enzyme in cholesterol biosynthesis, which catalyzes the reductive deacylation of HMG-CoA to mevalonate pathway, the metabolic pathway that produces cholesterol and other isoprenoids [10,11]. The high risk of coronary heart diseases or hyperlipidemia were found to be caused by elevated serum-blood cholesterol levels [12]. Decreasing total cholesterol levels is significantly regulated by the HMGR inhibitor enzyme. Furthermore, to prevent hypercholesterolemia, statins are very used as antihyperlipidemic drugs which bind into the active site of HMGR natural substrate [13]. However, some reports mentioned the disadvantages of this commercial drug due the side effects that it may have in vivo. In adverse, others demonstrated the importance of exploitation of natural compounds that may act as statins in order to have a lowering cholesterol levels by inhibition of HMGR within the cell [12].

Cancer, known as the disease of the century, is the primary cause of death in the globe after cardiovascular diseases [14,15]. One of the means of intervention is the inhibition of the proliferation cancer cell. The dietary consumption of polyphenols from herbs is associated with anticancer activity which has been suggested by epidemiology and considered to promote cancer reduction [16,17]. Therefore, several recent studies have focused on the development of new anti-tumor agents from natural products $[15,18]$.

Jujube is a thorny tree that belongs to the genus Zizyphus of the Rhamnaceae family. It is native to China, and distributed widely in the Europe, America, and Maghreb [19]. However, this plant contains a large quantity of primary metabolites with significant nutritional properties, namely proteins $(19.11 \pm 0.03 \%)$, lipids $(32.92 \pm 0.29 \%)$, and sugars $(40.87 \pm 0.39 \%)$ from which most studies on this plant are concentrated [20]. Among these substances, polyphenols from jujube, secondary metabolites of plants, are important determinants of the nutritional and organoleptic qualities of Zizyphus lotus [21,22]. Several bioactive compounds extracted from jujubes have attracted the attention of many researchers due to their important biological actions, including antioxidant [19,23], enzyme inhibitory [24,25], antiproliferative and cytotoxic effects [24,26], anti-inflammatory, and other effects [27-29], which can be used in the food, pharmaceutical, and cosmetic industry.

Several studies reported that innovative techniques are one of the most rapid methods for extraction of target compounds from plant materials. Among these, one of the simplified method in manipulation is ultrasound-assisted extraction (UAE) that was very used on extraction of phenolic compounds from different materials due to its high reproducibility and very appreciated for its reduction in solvent consumption [30,31]. Response surface methodology (RSM) is used as an effective statistical method for optimizing complex processes that reduce the number of experimental trials which is very used to evaluate interactions between multiple factors and the response variables that influence the results [14,32].

The diversity of the experiments made on the genus of Zizyphus indicates the biological potential of its bioactive components mainly polyphenols, proteins, and polysaccharides for all possible pharmaceutical 
and nutraceutical applications. To date, no data have evaluated the effect of ultrasound on polyphenols extracted from Zizyphus lotus seeds (Zls) and evaluation of its antioxidant, antiacetylcholinesterase, antihypercholesterolemia, and antiproliferative properties. The overall aim of this research work was to find out optimal extraction parameters (ethanol concentration, time, temperature, and solid/liquid ratio) for the valorization of phenolic compounds extracted from jujube seeds using green extraction technology under RSM model through the investigation of some biological effects of UAE extracts. This could be one of the economical solutions to valorize vegetable biomass in order to protect consumer and environment by consuming natural products and avoiding the generation of some industrial wastes. Additionally, it is one of the promotional strategies to meet the challenge in the 21st century through its uses on the development of new functional and nutraceutical ingredients in food and pharmaceutical industries with a high nutritional value.

\section{Materials and Methods}

\subsection{Plant Materials and Chemicals}

Jujube samples (Zizyphus lotus L.) were collected from Djelfa province of Algeria. Jujube seeds were cleaned and separated manually. Seeds were dried at $40{ }^{\circ} \mathrm{C}$ for $24 \mathrm{~h}$ in an oven (Memmert, Modell 100-800, Schwabach, Germany). The dried seeds were milled into fine powder $(<250 \mu \mathrm{m})$ which were frozen stored at $4{ }^{\circ} \mathrm{C}$ until analyses.

Folin-Ciocalteu, gallic acid were from Sigma Aldrich Co. (St. Louis, MO, USA). 1,1-diphenyl-2picrylhydrazyl radical (DPPH) was purchased from Sigma-Aldrich Chemie $\mathrm{GmbH}$ (Steinheim, Germany). Potassium ferricyanide $\left(\mathrm{C}_{6} \mathrm{~N}_{6} \mathrm{FeK}_{3}\right)$, ferric chloride $\left(\mathrm{FeCl}_{2} \cdot 6 \mathrm{H}_{2} \mathrm{O}\right)$, trichloroacetic acid, and sodium dihydrogen phosphate $\left(\mathrm{NaH}_{2} \mathrm{PO}_{4}\right)$ were bought from Biochem-chemopharma (UK). Acetylcholinesterase (AChE), acetylcholine iodide (AchI), 5-5' -dithiobis (2-nitrobenzoic acid) (DTNB), and HMG-CoA Reductase assay kit were obtained from Sigma (Barcelona, Spain). Roswell Park Memorial Institute (RPMI) medium 1640, Hank's balanced salt solution (HBSS) with and without phenol red, glutamine, 3-(4,5-Dimethylthiazol-2-yl)-2,5-diphenyltetrazolium bromide (MTT), trypsin, Dulbecco's modified Eagle medium (DMEM), glutamine, Pen-Strep (penicillin and streptomycin mixture), FBS (fetal bovine serum), and phosphate-buffered saline (PBS) were bought from Lonza (Verviers, Belgium). Magnesium chloride hexahydrate, hydrogen peroxide were purchased to PanReac (Barcelona, Spain). All other chemicals used in this study were from Sigma Aldrich.

\subsection{Ultrasound Assisted Extraction}

One gram of powder material was dissolved with the extracting solvent, introduced in an amber glass vial, and placed in a ultrasonic bath (J P.SELECTA 195W 50/60HZ, Barcelona, Spain) at $20 \mathrm{kHz}$. As previously stated, the suspension was exposed to ultrasonic waves allowing the appearance of cavitation pellets (Table 1). This last being very sensitive, was controlled by external frozen water circulation. After extraction, the extract was filtered through Whatman No. 1 paper and kept in shaded flasks at $4{ }^{\circ} \mathrm{C}$ for further analysis.

\subsection{Response Surface Methodology (RSM)}

In current study, a Box-Behnken design (BBD) experimental design with a total of 27 experiments based on the response surface methodology (RSM) was used to evaluate the effect of the independent variables including $X_{1}$ - Solvent concentration $(\% v / v), X_{2}$ - Sonication temperature $\left({ }^{\circ} \mathrm{C}\right), X_{3}$ - Sonication time $(\mathrm{min})$, and $X_{4}$ - Solvent- solid ratio $(\mathrm{mL} / \mathrm{g})$. The concentrations are indicated in Table 1 and used for each test as indicated in Table 2, Total Phenolic Content (TPC) was determined and used for estimating the parameters in the following equation. After estimating these parameters, the prediction of the of 
the TPC yields on jujube seeds extracts was performed following the second order experimental model according to Equation (1).

$$
y=B_{0}+\sum_{i=1}^{k} B i X i+\sum_{i=1}^{k} B i i X^{2}+\sum_{i>1}^{k} B i i X i X j+E
$$

where $y$ represents the predicted response which is TPC yield; $\beta$ is a constant coefficient; $\beta i, \beta i i, \beta i j$ are regression coefficients for linear, quadratic, and interactive terms, respectively; and Xi and Xj represent the coded independent variables while $\mathrm{E}$ is error. The significance and suitability of the model was analyzed by the variance (ANOVA) using JMP.

\subsection{Analytical Determinations}

\subsubsection{Total Phenolic Content (TPC)}

The TPC yield was determined for Zls extracts according to the color method based on Folin-Ciocalteu reaction [19]. The results were expressed as $\mathrm{mg}$ gallic acid equivalent per $100 \mathrm{~g}$ of dry matter (mg GAE/100 g).

Table 1. Box-Behnken design with the observed responses and predicted values of Total Phenolic Content (TPC) from Z.lotus seeds using ultrasound-assisted extraction (UAE).

\begin{tabular}{|c|c|c|c|c|c|c|}
\hline Run & $\begin{array}{c}X_{1}- \\
\text { Ethanol } \\
\text { Concentration } \\
(\% v / v)\end{array}$ & $\begin{array}{c}X_{2}- \\
\text { Sonication } \\
\text { Temperature }\end{array}$ & $\begin{array}{c}X_{3}- \\
\text { Sonication } \\
\text { Time (Min) }\end{array}$ & $\begin{array}{c}X_{4}- \\
\text { Solvent- } \\
\text { Solid Ratio } \\
(\mathrm{mL} / \mathrm{g})\end{array}$ & Experimental & Predicted \\
\hline 1 & 50 & 30 & 10 & 25 & 1643.19249 & 1683.34855 \\
\hline 2 & 50 & 20 & 15 & 25 & 1877.93427 & 1895.48557 \\
\hline 3 & 20 & 30 & 15 & 25 & 1525.8216 & 1497.67432 \\
\hline 4 & 80 & 30 & 15 & 25 & 1154.14711 & 1117.74039 \\
\hline 5 & 50 & 40 & 15 & 25 & 1760.56338 & 1734.20927 \\
\hline 6 & 50 & 30 & 20 & 25 & 1741.00157 & 1774.20231 \\
\hline 7 & 50 & 20 & 10 & 30 & 1956.18153 & 1889.99739 \\
\hline 8 & 20 & 30 & 10 & 30 & 1314.55399 & 1308.63111 \\
\hline 9 & 80 & 30 & 10 & 30 & 1377.1518 & 1353.84064 \\
\hline 10 & 50 & 40 & 10 & 30 & 1791.86229 & 1786.75448 \\
\hline 11 & 20 & 20 & 15 & 30 & 1658.84194 & 1701.38889 \\
\hline 12 & 80 & 20 & 15 & 30 & 1314.55399 & 1382.74865 \\
\hline 13 & 50 & 30 & 15 & 30 & 2230.04695 & 2310.90245 \\
\hline 14 & 50 & 30 & 15 & 30 & 2425.6651 & 2310.90245 \\
\hline 15 & 50 & 30 & 15 & 30 & 2276.99531 & 2310.90245 \\
\hline 16 & 20 & 40 & 15 & 30 & 1384.97653 & 1410.35255 \\
\hline 17 & 80 & 40 & 15 & 30 & 1408.4507 & 1459.47444 \\
\hline 18 & 50 & 20 & 20 & 30 & 2057.90297 & 2036.2763 \\
\hline 19 & 20 & 30 & 20 & 30 & 1674.49139 & 1630.96635 \\
\hline 20 & 80 & 30 & 20 & 30 & 1377.1518 & 1316.23848 \\
\hline 21 & 50 & 40 & 20 & 30 & 1885.759 & 1925.20866 \\
\hline 22 & 50 & 30 & 10 & 35 & 1990.08868 & 2050.45862 \\
\hline 23 & 50 & 20 & 15 & 35 & 2300.46948 & 2259.98739 \\
\hline 24 & 20 & 30 & 15 & 35 & 1661.45018 & 1671.12241 \\
\hline 25 & 80 & 30 & 15 & 35 & 1780.1252 & 1781.53799 \\
\hline 26 & 50 & 40 & 15 & 35 & 2291.34064 & 2206.95314 \\
\hline 27 & 50 & 30 & 20 & 35 & 2190.92332 & 2244.33794 \\
\hline
\end{tabular}


Table 2. Analysis of variance (ANOVA) for the experimental results obtained by using UAE.

\begin{tabular}{|c|c|c|c|c|c|c|}
\hline Parameter $^{\mathbf{a}}$ & $\begin{array}{c}\text { Estimated } \\
\text { Coefficients }\end{array}$ & $\begin{array}{l}\text { Standard } \\
\text { Error }\end{array}$ & $\mathrm{DF}^{\mathrm{b}}$ & $\begin{array}{l}\text { Sum of } \\
\text { Squares }\end{array}$ & F-Value & Prob $>$ F \\
\hline $\begin{array}{l}\text { Model } B_{0} \\
\text { Linear }\end{array}$ & 2310.9025 & 42.28475 & 14 & $3,245,323.8$ & 43.2157 & $<0.0001$ * \\
\hline$X_{1}$-Ethanol & -67.37959 & 21.14238 & 1 & $54,480.1$ & 10.1566 & $0.0078 *$ \\
\hline$X_{2}$-Temperature & -53.57764 & 21.14238 & 1 & $34,446.8$ & 6.4218 & $0.0262 *$ \\
\hline$X_{3}$-Time & 71.183272 & 21.14238 & 1 & $60,804.7$ & 11.3357 & $0.0056 *$ \\
\hline$X_{4}$-Ratio & 209.31142 & 21.14238 & & $525,735.3$ & 98.0118 & $<0.0001$ * \\
\hline \multicolumn{7}{|l|}{ Quadratic } \\
\hline$X_{1}^{2}$ & -664.7757 & 31.71357 & 1 & $2,356,942.5$ & 439.4001 & $<0.0001$ * \\
\hline$X_{2}{ }^{2}$ & -157.6356 & 31.71357 & 1 & $132,528.0$ & 24.7069 & $0.0003 *$ \\
\hline$X_{3}^{2}$ & -243.7076 & 31.71357 & 1 & $316,764.8$ & 59.0538 & $<0.0001 *$ \\
\hline$X_{4}^{2}$ & -129.108 & 31.71357 & & $88,900.6$ & 16.5736 & $0.0016^{*}$ \\
\hline \multicolumn{7}{|l|}{ Interaction } \\
\hline$X_{1} X_{2}$ & 91.940532 & 36.61967 & 1 & $33,812.2$ & 6.3035 & $0.0274 *$ \\
\hline$X_{1} X_{3}$ & -89.98435 & 36.61967 & 1 & $32,388.7$ & 6382 & $0.0302 *$ \\
\hline$X_{1} X_{4}$ & 122.58738 & 36.61967 & & $60,110.7$ & 11.2063 & $0.0058 *$ \\
\hline$X_{2} X_{3}$ & -1.956182 & 36.61967 & 1 & 15.3 & 0.0029 & 0.9583 \\
\hline$X_{2} X_{4}$ & 27.060511 & 36.61967 & & 2929.1 & 0.5461 & 0.4741 \\
\hline$X_{3} X_{4}$ & 25.75639 & 36.61967 & & 2653.6 & 0.4947 & 0.4953 \\
\hline Lack of Fit & & & 10 & $43,510.243$ & 0.4172 & 0.8589 \\
\hline Pure Error & & & 2 & $20,857.773$ & & \\
\hline Total Error & & & 12 & $64,368.016$ & & \\
\hline $\mathrm{R}^{2}$ & & & & & 0.980552 & \\
\hline $\mathrm{R}^{2}$ Adjusted & & & & & 0.957862 & \\
\hline $\mathrm{CV} \%$ & 4.11 & & & & & \\
\hline RMSE & 73.23934 & & & & & \\
\hline Corr.Total & & & 26 & $33,09691.8$ & & \\
\hline
\end{tabular}

\subsubsection{Total Flavonoids Content (TFC)}

The TFC yield was measured for $\mathrm{Zls}$ extracts, using methanolic aluminium chloride $\left(\mathrm{AlCl}_{3}\right)$ for $2 \%$ as described in Ghafar, et al. [33]. The results were expressed as mg quercetin equivalents per $100 \mathrm{~g}$ of dry matter (mg QE/100 g).

\subsubsection{Total Condensed Tannins Content (TTC)}

The TTC yield was determined using the method of Hagerman [34] and the results were expressed as $\mathrm{mg}$ catechin equivalent per $100 \mathrm{~g}$ of dry matter ( $\mathrm{mg} \mathrm{CE} / 100 \mathrm{~g}$ ).

\subsubsection{Antioxidant Activity by DPPH and FRAP Assays}

The radical-scavenging activity (DPPH) and ferric reducing antioxidant power (FRAP) of $\mathrm{Zls}$ extracts was measured by the methods adapted from those reported by Hammi, et al. [35]. Results were expressed as the percentage of DPPH, calculated following the equation below (Equation (2)):

$$
\mathrm{DPPH} \%=\left[\left(\mathrm{A}_{\mathrm{b}}-\mathrm{A}_{\mathrm{s}}\right) / \mathrm{A}_{\mathrm{DPPH}}\right] \times 100
$$

where $A_{b}, A_{s}$, and $A_{D P P H}$ were the absorbance value of blank, diluted extract, and control, respectively. The radical-scavenging activity (EC50) is defined as the concentration of Zls extracts that provided $50 \%$ of DPPH free radicals. However, FRAP assay was expressed in terms of antioxidants having an iron reduction capacity equivalent to that of equivalents in gallic acid of $1 \mathrm{mg}$ per $100 \mathrm{~g}$ of dry matter (mg GAE/100 g). 


\subsubsection{AChE and HMGR Inhibitions Tests}

Anticholinesterase activity was determined using AChE assay according to what was previously reported [36]. Briefly, $100 \mu \mathrm{L}$ of distillated water was added to $325 \mu \mathrm{L}$ of $50 \mathrm{mM}$ Tris buffer (pH 8) and $25 \mu \mathrm{L}$ of AChE solution. The solution was mixed and incubated for $15 \mathrm{~min}$ at $25^{\circ} \mathrm{C}$. Subsequently, $75 \mu \mathrm{L}$ of AChI solution $(\mathrm{mg} / \mathrm{mL})$ and $475 \mu \mathrm{L}$ of DTNB $(1.2 \mathrm{mg} / \mathrm{mL}$ of $50 \mathrm{mM}$ Tris buffer $(0.1 \mathrm{M} \mathrm{NaCl}$ and $0.02 \mathrm{M} \mathrm{MgCl}_{2}$ ) at $\mathrm{pH} 8$ ) were added. The absorbance was read for 4 min with $30 \mathrm{~s}$ intervals and the initial velocity was calculated at $405 \mathrm{~nm}$ on the spectrophotometer Schimadzu UV-160A, Kyoto, Japan. A control reaction was carried out using the same procedure but with adding $100 \mu \mathrm{L}$ of distillated water instead of $100 \mu \mathrm{L}$ of $\mathrm{Zls}$ extract at different concentrations. All tests were done in triplicate and the percentage inhibition was calculated as

$$
I(\%)=100-(\text { Vsample } / \text { Vcontrol }) \times 100
$$

where $I$ is the percent inhibition of acetylcholinesterase, Vsamples the initial velocity of the extract containing reaction, and Vcontrols the initial velocity of the control reaction.

The inhibition of the enzymatic activity of 3-hydroxy-3-methylglutaryl reductase (HMGR) was measured using the oxidation of nicotinamide adenine dinucleotide phosphate hydrate (NADPH) in triplicate [37]. Briefly, at $0,1,2,4$, and $6 \mathrm{~min}$, aliquots were removed and then the reaction was stopped by adding methanol (50\%). The amount of NADPH wasanalyzed by HPLC-DAD using VWR-Hitachi Elite LaChrom ${ }^{\circledR}$, Tokyo, Japan. In order to evaluate the decrease of the peak area over time, which allowed to make a linear regression and to obtain the reaction velocity, the decrease in activity was monitored at $340 \mathrm{~nm}$. The activity value without inhibitor was considered to be $100 \%$. The $\mathrm{IC}_{50}$ values were determined from regression curves by plotting inhibition as a function of the concentration of inhibitor.

\subsubsection{Anti-Proliferative Activities on $\mathrm{HepG}_{2}$ and MCF-7 Cells}

The cytotoxicity of Zls extracts were performed using the MTT viability test, against the human tumor cell lines HepG 2 (ATCC\#HB-8065), from human hepatocellular liver carcinoma cell lines, and MCF-7 HTB-22), from breast cancer, were cultured in DMEM supplemented with 10\% FBS, $100 \mathrm{U} / \mathrm{mL}$ Pen-Strep, and $2 \mathrm{mM} \mathrm{L-glutamine}$ at $37^{\circ} \mathrm{C}$ in an atmosphere containing $5 \% \mathrm{CO}_{2}$ every 48 to $72 \mathrm{~h}$ before reaching confluence, the medium was changed [10]. For each concentration of extract, the assays were done in $8 \times 12$ replicates and the cell viability percentage was calculated by the following equation (Equation (4)):

$$
\begin{aligned}
& \text { Viability }(\%) \\
& =[(\text { Abs } 595-\text { Abs } 630 \text { of experimental wells }) /(\text { Abs } 595-\text { Abs } 630 \text { of control wells })] \times 100
\end{aligned}
$$

\subsection{Statistical Analysis}

In order to see the effect of UAE obtained from the Box Behnken Design (BBD) trials, ANOVA analysis was used in this study. Each extraction trial and all the analyses were carried out in triplicate. The JMP (Version 10.0, SAS) was used to construct the BBD and to analyze ANOVA results.

\section{Results and Discussion}

\subsection{Optimization Study by RSM Using UAE Technology}

\subsubsection{Model Parameter Estimation}

The factorial experimental design based on a BBD using UAE method and corresponding responses for the obtaining of TPC from Zls extracts was investigated and presented at various conditions with a model of the total of 27 experiments in Table 2. In order to estimate experimental error measurement, 
three replications at the central points were made [38]. The factors studied were ethanol concentration, sonication temperature, sonication time, and solvent/solid ratio, which is ethanol/seed quantity. These factors were used in the in the range indicated in Table 1 . The parameters were estimated from the experimental TPC results and ANOVA analysis was carried out to determine the applicability of the model, Table 2.

The second order polynomial equation was generated to describe the empirical relationship between the Zls extract and operational conditions in terms of coded values. The mathematical models were simplified by neglecting statistically the insignificant terms $(p>0.01)$ following predictive equation:

$$
\begin{aligned}
& Y=2310.90-60.37 X_{1}-53.57 X_{2}+71.18 X_{3}+209.31 X_{4} \\
& -664.77 X_{1}^{2}-157.63 X_{2}^{2}-243.70 X_{3}^{2}-129.10 X_{4}^{2}+91.94 X_{1} X_{2}-89.98 X_{1} X_{3}+122.58 X_{1} X_{4}
\end{aligned}
$$

It can be seen that all factors influence the extraction yield as linear and quadratic effects, but the interaction effects were significant for all the four parameters, positive for ethanol concentration and sonication temperature, negative for ethanol concentration and sonication time. While, positive also for ethanol concentration and solvent-solid ratio which was highly significant then the others. On the other side, it can be seen in Equation (3) that $X_{2} X_{3}, X_{2} X_{4}, X_{3} X_{4}$ didn't exhibit any significant effect on extraction yield (Table 2).

However, if there is any significance of each factor, it was demonstrated by a presence of $p<0.05$ and the contrary, it was also demonstrated $p$-values $(p<0.001)$ which indicates high significance. Very low $p$-values $(p<0.0001)$ indicated that each generated model was statistically significant and suggests that the UAE of $Z l s$ could be well described with those appropriate models.

The values of $R$-squared are close to 1 for the model ( 0.98 and 0.95 for $R^{2}$ and $R^{2}$, adjusted respectively), which are very high and indicates a good correlation between the experimental and the predicted values, also indicated that $98 \%$ could be explain by the model of the variation in the TPC extracts using UAE method. In addition, other parameters were insignificants as F-value for the lack of fit $(p>0.05)$ and values of coefficient of variation $(C V=4.11)$ which provide also the validity of the deduced model.

\subsubsection{Effect of Experimental Conditions on TPC, TFC, and TTC Extraction Yield}

The influence of the four parameters on TPC yields is shown in Figure 1.

Confirming the results of the single-factor trials, Figure 1a-c shows that the TPC yield reached a maximum level when ethanol concentration was set at medium levels ( 0 coded value) as it mentioned in Table 2, we can notice that the yield of TPC using UAE mainly depends on the ethanol concentration as its quadratic, interaction and linear effects were highly significant $(p<0.01)$, which showed the increase on TPC for all other parameters.

Figure $1 \mathrm{c}-\mathrm{f}$ shows that the interaction effect of temperature with other factors on TPC yield that was very limited and stable as demonstrated in the equation model. Thus, only the Figure 1c showed a positive influence of both ethanol and temperature on the TPC extraction and the decrease of TPC recovery from the other figures is mainly associated to their thermal degradation at higher temperature.

However, Figure $1 \mathrm{~b}-\mathrm{e}$ shows that maximum extraction TPC yield was for $2100 \mathrm{mgGAE} / 100 \mathrm{~g}$ when using a ratio about $30(\mathrm{~mL} / \mathrm{g}, v / w)$ over a range of temperature and time factors, in contrary in interaction with ethanol concentration which was very significant as confirmed also as positive effect in Table 2. The increase in TPC was deemed by the effects of acoustic cavitation that contribute to the formation and rupture of cavitation bubbles and then facilitate the mass transfer of the process, while, TPC started to decrease after higher increase in ratio which may affect the dispersion of the ethanol under ultrasound energy density [39].

Furthermore, Figure $1 \mathrm{f}$ shows the interaction effect between temperature and time sonication. It is obvious that longer sonication time increases the extraction yield for polar compounds in hydro-alcoholic solvent. While, the prolonged exposures at higher temperature decrease significatively the TPC recovery due to their thermal degradation which confirmed the results of Table 2. 


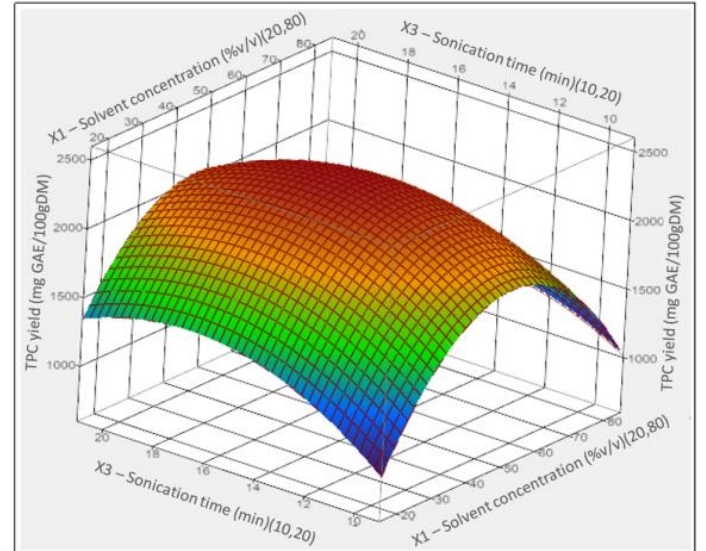

(a)

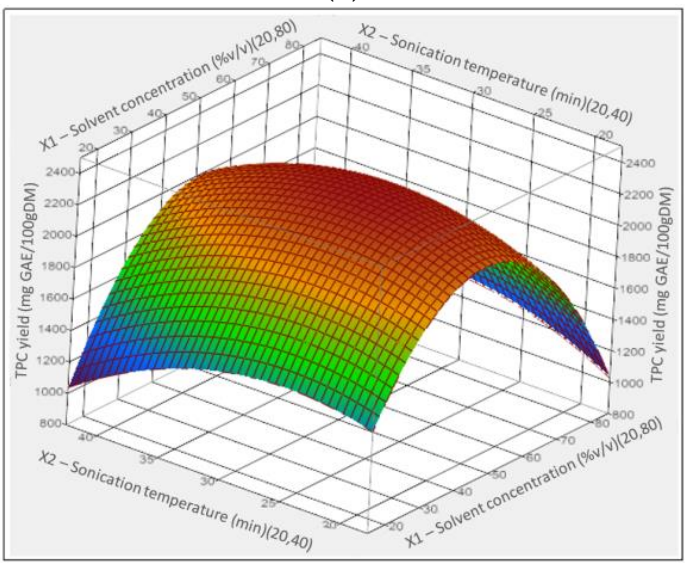

(c)

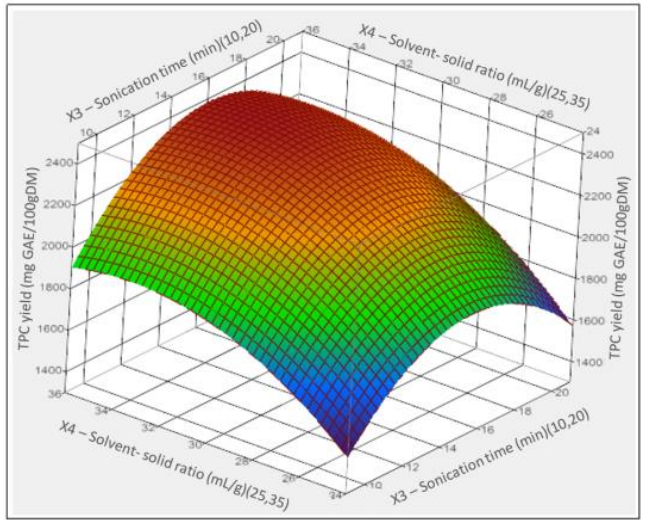

(e)

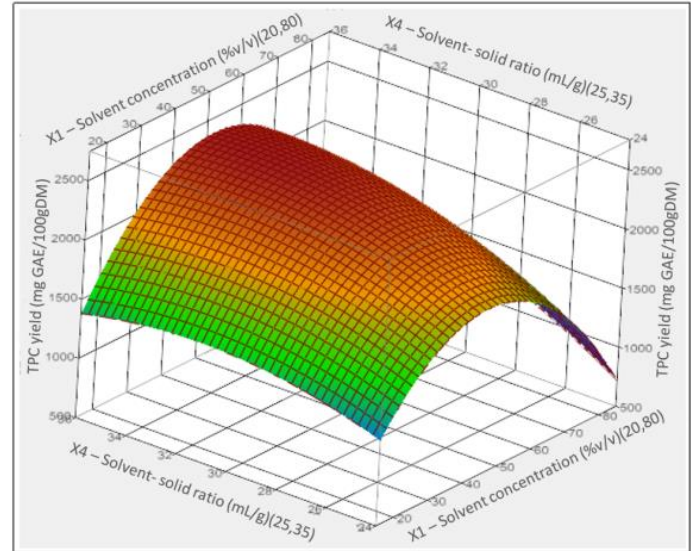

(b)

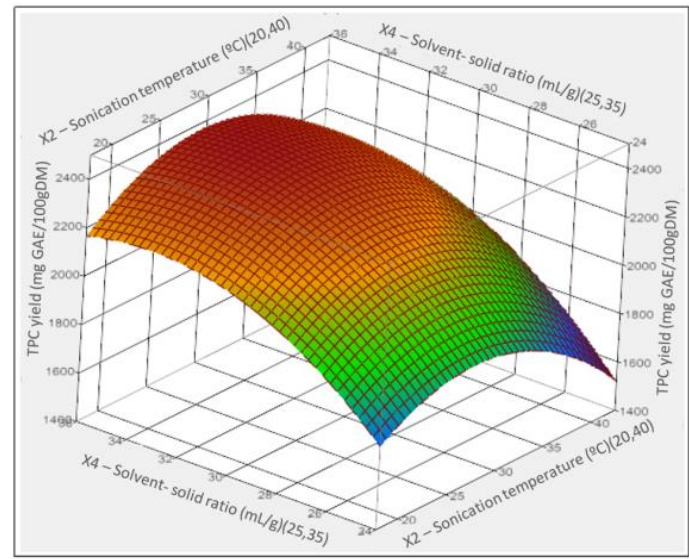

(d)

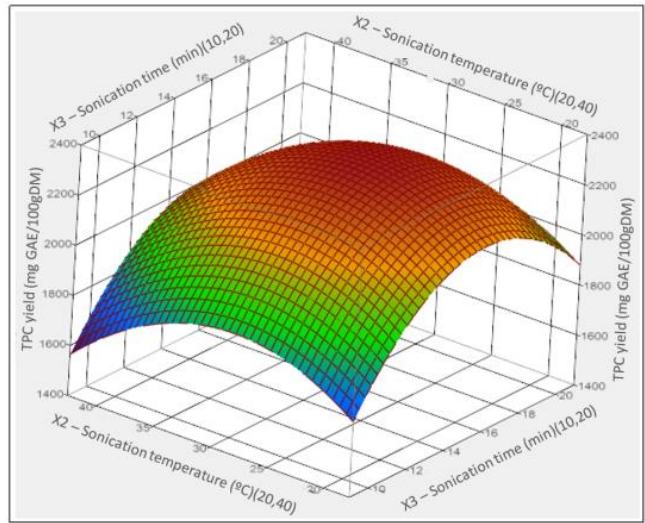

(f)

Figure 1. Response surface analysis for the total phenolic yield from Z.lotus seeds using UAE with respect to sonication time and ethanol concentration (a); solvent-to-solid ratio and ethanol concentration (b); sonication temperature and ethanol concentration (c); solvent-to-solid ratio and sonication temperature (d); solvent-to-solid ratio and sonication time (e); sonication temperature and sonication time (f).

The prediction values for the optimal TPC extraction were verified experimentally. Optimal conditions resulted in ethanol concentration $50.16 \%$, sonication temperature $29.01^{\circ} \mathrm{C}$, sonication time $15.94 \mathrm{~min}$ and solvent-to-solid ratio $34.1 / 1 \mathrm{~mL} / \mathrm{g}$ with a predicted TPC yield of $2406.08 \pm 79.87 \mathrm{mgGAE} / 100 \mathrm{~g}$ (Figure 2). 


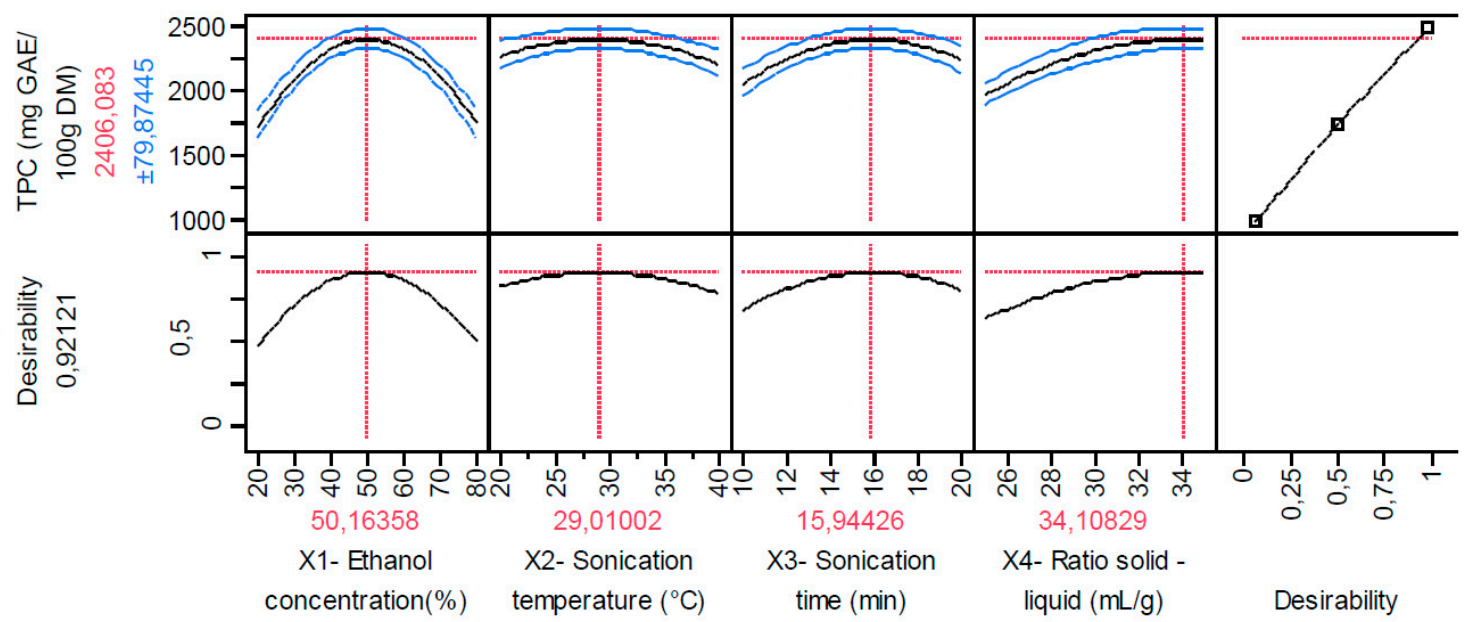

Figure 2. Prediction Profiler of Z.lotus seeds extract using UAE.

The UAE was carried out at these optimal conditions obtaining a TPC yield of $2383.10 \pm 0.87 \mathrm{mgGAE} / 100 \mathrm{~g}$, very close to the value predicted by the model (Table 3). This result indicates that $\mathrm{Zls}$ showed a significantly higher TPC recovery in comparison to TPC obtained from other plants. In the meanwhile, the ethanol/water mixture showed a high extraction efficiency by ultrasound and this was in agreement with other studies showing a great effect of ethanol concentration for phenolic compounds extraction, from Citrus limon fruit using $63.93 \%$ of ethanol (1502.2 $\pm 0.88 \mathrm{mgGAE} / 100 \mathrm{~g}$ ) [32]. Similarly, from Pistacia lentiscus leaves that obtaining a lower TPC value of $1420.76 \pm 19.98 \mathrm{mgGAE} / 100 \mathrm{~g}$ [40]. More recently, Esmaeelian, et al. [41] have shown a lower TPC value from Crocus sativus L. corms extract than our result (100.39 mgGAE/100 g dry saffron corm) using 80\% of ethanol. The extraction process used in the present work give higher TPC than Indian jujube cultivars using conventional extraction method ranging from 172.08 to $328.65 \mathrm{mgGAE} / 100 \mathrm{~g}$ with $80 \%$ of ethanol [42]. Similarly, higher TPC recovery than work of Al-Saeedi, et al. [43] from Oman Zizyphus jujuba fruit which has a content of $64.89 \pm 0.44 \mathrm{mg} \mathrm{GAE} / 100 \mathrm{~g}$ using methanol as extraction solvent. More recently, Noriega-Rodríguez, et al. [44] found a TPC value of $2.16 \mathrm{~g}$ gallic acid equivalent (GAE)/100 $\mathrm{g}$ from Globe artichoke (Cynara scolymus L.) using conventional extraction method with $75 \%$ of ethanol which is lower than jujube extract. To note, these results show the efficiency of extraction of the phenolic compounds using the hydro-alkolic solvent which makes it possible to increase the polarity, and thus the solubility of the solid ratio that increased the extraction yield beside the other factors.

However, the TFC using UAE (Table 3) was found to be significantly higher (486.50 $\pm 0.38 \mathrm{mg}$ QE/100 g) than those obtained from Zizyphus jujuba seeds using ethanol $70 \%$ by ultrasound extraction method (200.01 $\pm 0.15 \mathrm{mg} / 100 \mathrm{~g}$ ) [45]. Similarly, our extract showed a significantly higher TFC than Zizyphus jujuba fruits extract obtained at different stage of ripening, ranging from 26.7 to $48.5,19.9$ to $34.6 \mathrm{mg} \mathrm{QE} / 100 \mathrm{~g}$ in "Ya Tsao", "Ta-Jan Tsao" cultivars, respectively [46].

Regarding to the TTC yields, the Zls extract was for 15,787.10 $\pm 0.10 \mathrm{mg} \mathrm{CE} / 100 \mathrm{~g}$ (Table 3), which is five times higher than that of polymeric proanthocyanidins extracted from Zizyphus jujuba fruits, which was between 939 and $2548 \mathrm{mg} / 100 \mathrm{~g}$ in depends on cultivars [47]. The present work suggests that UAE method is an efficient alternative to other extraction techniques for extracting and maximizing polyphenols from $\mathrm{Zls}$ in short extraction time and jujube seeds is a non-negligible source of polyphenols. 
Table 3. Biological activities of Z. lotus seeds extract using UAE. Results are expressed as means \pm standard deviation.

\begin{tabular}{lc}
\hline \multicolumn{1}{c}{ Factors } & Ultrasound Extraction \\
\hline Sonication time $(\mathrm{min})$ & 15.94 \\
Ethanol concentration $(\%)$ & 50.16 \\
Sonication temperature $\left({ }^{\circ} \mathrm{C}\right)$ & 29.01 \\
Solvent solid/ratio $(\mathrm{mL} / \mathrm{g})$ & 34.10 \\
\hline Results & \\
\hline Recovery of TPC $(\mathrm{mg} \mathrm{GAE} / 100 \mathrm{~g})$ & $2383.10 \pm 0.87$ \\
Recovery of TFC $(\mathrm{mg} \mathrm{QE} / 100 \mathrm{~g})$ & $486.50 \pm 0.38$ \\
Recovery of TTC $(\mathrm{mg} \mathrm{CE} / 100 \mathrm{~g})$ & $15,787.10 \pm 0.10$ \\
DPPH scavenging EC $50(\mu \mathrm{g} / \mathrm{mL})$ & $0.39 \pm 0.00$ \\
FRAP $(\mathrm{mg}$ GAE/100 g) & $1670.42 \pm 6.50$ \\
AChE assay IC $50(\mathrm{mg} / \mathrm{mL})$ & $0.93 \pm 0.01$ \\
HMGR assay $(\%)(\mathrm{for} 100 \mu \mathrm{g} / \mathrm{mL})$ & 45.41 \\
HepG2 cells $\mathrm{IC}_{50}(\mathrm{mg} / \mathrm{mL})$ & $3 \pm 0.50$ \\
MCF-7 cells $\mathrm{IC}_{50}(\mathrm{mg} / \mathrm{mL})$ & $<0.05 \pm 0.0$ \\
\hline
\end{tabular}

\subsection{Biological Activities}

\subsubsection{Antioxidants Activity of Zls Extract}

The imbalance between the production of reactive oxygen species (ROS) and the biological system's antioxidant defenses is defined as the oxidative stress. This proved in several studies to develop a lot of diseases. In order to protect our human body from these diseases, the antioxidants are showed to be effective for neutralization of free radicals [14]. However, to determine whether the UAE extraction process impact the biological functions, the antioxidant effects of jujube seeds extracts were examined and evaluated by DPPH radical scavenger and FRAP model (Table 3).

The DPPH scavenging assay of the Zls extract revealed a significant highest activity with lowest $E_{50}$ value $(0.39 \mu \mathrm{g} / \mathrm{mL})$ than that of Tunisian $Z$. lotus leaves and fruits extract using methanol $(0.10 \pm 0.001$ and $0.31 \pm 0.005 \mathrm{mg} / \mathrm{mL})$ [48], Tunisian Z. lotus pulp and peel extracts using UAE with an $\mathrm{EC}_{50}$ of $0.28 \mathrm{mg} / \mathrm{mL}$ [19], from Z. mucronata roots $(0.029 \pm 0.05 \mathrm{mg} / \mathrm{mL})$ [49], and from Korian Z. jujuba seeds (mechu and sanzoin) (0.3 and $0.1 \mathrm{mg} / \mathrm{mL}$ ), respectively [50]. Overall, this study showed that $Z l s$ extracts exhibited a high antioxidant effect in comparison to some Zizyphus species using both UAE and conventional methods. Furthermore, $\mathrm{Zls}$ extract by UAE exhibited a significant iron-reducing power $(1670.42 \pm 6.5 \mathrm{mg} / 100 \mathrm{~g})$ and was found to be higher than those obtained with $471.6 \pm 30.8 \mathrm{mg} / 100 \mathrm{~g}$ from Z. jujuba cv. Zaowangzao [51].

Thus, this paper revealed the effectiveness of ultrasound method for extraction of polyphenols from jujube seeds with significant antioxidant activities in comparison to conventional methods that gave lower recovery and activity which could be attributed to the mechanic cavitation of ultrasound due to the acoustic bubbles which results to enhanced desired compounds without altering its quality. The inhibition of DPPH as well as the iron chelating effect are probably due to the significant jujube content in photochemical substances especially in phenolic compounds, the latter having powerful reducing effects of oxidation. In addition, from other jujube extracts that contain other compounds namely ascorbic acid, tocopherol, and pigments, were found to present synergic effects between them and contribute to the total antioxidant activity of this extract, and therefore the trapping of free radicals. While, this suggested that not only phenolic compounds present in the jujube extract can act as antioxidants but also other compounds may be responsible for this activity [52-54]. In our case, the antioxidant activity using DPPH and FRAP methods from Zls extract is in perfect agreement with other research showing that there can be correlation between the phenolic content and the antioxidant capacity [55]. 


\subsubsection{AChE Inhibition of Zls Extract}

The antiacetylcholinesterase activity of the Zls extract are presented in the Table 3. The rapid hydrolysis of ACh following the stopping of the transmission of nerve impulses to cholinergic synapses is well controlled by the role of AChE. One of the ways deemed effective used against AD is more particularly based on the inhibition of $\mathrm{AChE}$, which makes it possible to maintain the levels of acetylcholine for the transmission of nerve impulses [56]. The anticholinesterase activity of jujube extract at different concentrations exhibited inhibitory activity with an $\mathrm{IC}_{50}$ value of $0.93 \pm 0.01 \mathrm{mg} / \mathrm{mL}$. These results are higher than that obtained from Zizyphus oxyphylla extracts using $n$ - butanol which showed a maximum inhibitory effect with an $\mathrm{IC}_{50}$ value of $9.58 \pm 0.08 \mathrm{mg} / \mathrm{mL}$ [57]. This demonstrated the good effect of the used method mainly the good extraction yield of many compounds from $\mathrm{Zls}$, ethanol/water used for extraction and ultrasounds cavitation of $\mathrm{Zls}$ which exhibited a good inhibition of AChE which can be applicable against AD. Ethanol concentration is considered as a crucial factor in UAE due to cavitation phenomena enhancing solvent penetration into jujube extract [32]. Moreover, the Zls extract is approximatively in the same range than Tunisian Zls extract [58] using acetone for extraction by maceration method $(0.85 \mathrm{mg} / \mathrm{mL})$. However, in comparison to other plants that used acetone also, our extract had a highest AChE inhibitory effect than that obtained from Herniaria fontanesii and Hyoschy amusalbus with an $\mathrm{IC}_{50}$ value of 1 and $1.17 \mathrm{mg} / \mathrm{mL}$, respectively [58]. Thus, our results suggested that extraction using ultrasounds under different conditions mainly ethanol as solvent extraction is an important parameter to take into account in AChE tests. Furthermore, Fucus vesiculosus extracts from Tagus estuary presented an $\mathrm{IC}_{50}$ of $840.85 \mu \mathrm{g} / \mathrm{mL}$ which is in well agreement than our AChE inhibitory from Zls. In addition, the standard galantamine showed an $\mathrm{IC}_{50}$ of $0.14 \mu \mathrm{g} / \mathrm{mL}$ that is lower than these extracts [59]. These suggests that the intestinal motility may be affected by its consumption although with a much less effect comparatively to the chemical drugs [37]. Major medicinal plant extracts showed some level of inhibitory activity against the AChE. This could be attributed to the phytochemicals mostly phenolic compounds present in the extract and their possible synergistic interaction effect [59-64]. To the best of authors knowledge, this is the first report on in vitro inhibition of the AChE enzyme by Zls extracts under the effect of ultrasound extraction where the interest of its application against Alzheimer's disease.

\subsubsection{HMGR Inhibition of Zls Extract}

The HMGR inhibition by the Zls extract is demonstrated, at the concentration of $100 \mu \mathrm{g} / \mathrm{mL} \mathrm{Zls}$ ethanolic extracts showed an activity of $45.41 \%$ as a HMGR inhibitors which is higher than the acetone and ethanol extracts from lichen $U$. complanata with 2.22 and $21.48 \%$, respectively, at the concentration of $60 \mu \mathrm{g} / \mathrm{mL}$ [12]. Similarly, Peganumarma and Tencriumpolium from aerial parts extracts showed a value of 28.5 and $28.8 \%$ of HMGR inhibition which are lower than our sample [65]. However, Zls extract showed a significant HMGR inhibitory effects than seeds extracts of some species, mainly Cannabis sativa $(7.4 \%)$, Cuminum cyminum (26\%), and Pimpinella anisum (10.5\%) [65]. The $\mathrm{IC}_{50}$ of the drug simvastatin was found to be around $0.198 \pm 0.015 \mathrm{~g} / \mathrm{mL}$, which is lower than the value determined for the Zls extract, therefore a higher activity than that observed in our extract. These are in good agreement to our previous results from Centaurium erythraea extracts [37]. However, this drug is a pure compound while $Z l s$ is a mixture of several compounds some of which may show significant activities but which are masked in the mixture [59]. Several bioactive compounds mainly polyphenols, saponins, alkaloids, and triterpenes were found to have a good hypolipidemic activity against HMGR [66-68]. Thus, jujube extract was found as a modest HMGR inhibitors which is due to the presence of some bioactive compounds that may be responsible for this enzyme inhibition like all polar plant extracts found in literature $[66,67]$. The properties of our sample phytochemicals make them possible antihyperlipidemic applications by fitting the enzyme active site.

Furthermore, other Zizyphus species (Z. mauritiana) leaves extracts were used previously for the treatment of fatty liver and atherosclerosis by reducing cholesterol and triglyceride and levels [69]. Among some studies that have shown the effect of polyphenols in inhibiting the action of HMG-CoA, 
demonstrated that curcumin, tetrahydrocurcumin, epigallocatechin-3-gallate, and kaempferol among all the other polyphenols tested can occupy the HMG-CoA binding site on the NADP+ site which utilizes two molecules of nicotinamide adenine dinucleotide phosphate-oxidase (NADP $[\mathrm{H}]$ ); thus, can play the role of competitive inhibitors of substrate binding to enzyme that can block the electron transfer on the substrate HMG-CoA [70]. Compelling effect of these compounds and major phenolic compounds in general indicates the importance of their uses for the cholesterol-lowering in order to the maintenance of cardiovascular health [71,72].

\subsubsection{Anti-Proliferative Activity of Zls Extract}

The in vitro evaluation of Zls extracts on cytotoxicity effects were analyzed. The toxicity of extracts was tested in the human cell lines $\mathrm{HepG}_{2}$ and MCF-7 using 5 serial concentrations ranging from 0.05 to $1 \mathrm{mg} / \mathrm{mL}$ of extract in order to calculate the cell viability. The $\mathrm{IC}_{50}$ values which confirm the concentration of extracts that killed $50 \%$ of the cells was obtained from dose-response curves. The phenolic compounds of $Z l s$ studied were revealed to be non-toxic towards only to $\mathrm{HepG}_{2}$ cell line because the value is higher than $0.1 \mathrm{mg} / \mathrm{mL}$. This value is considered as limit of toxicity to human cell lines [73]. In contrary, Zls extract analyzed against toxicity in MCF-7 cells showed an $\mathrm{IC}_{50}$ value lower than $0.05 \mathrm{mg} / \mathrm{mL}$ which is considered toxic to human cell lines. The value of $1 \mathrm{mg} / \mathrm{mL}$ which correspond to the maximum concentration present in the UAE extract inhibited $70.84 \%$ and $26.21 \%$ for MCF-7 and $\mathrm{HepG}_{2}$ cells, respectively. Thus, $\mathrm{Zls}$ extract exhibited no significant activity against $\mathrm{HepG}_{2}$ cells. In contrary, it exhibited a significant activity against MCF-7 cells. These findings can be due to the main bioactive compounds contained in Zls extract that may include flavonoids, tannins, alkaloids, terpenoids, and saponins as observed previously from other jujube species and from other part of Zizyphus lotus which showed a strong antiproliferative activity against $\mathrm{HepG}_{2}$ and MCF-7 cells [21,74].

In addition, $Z$. jujube fruits extract was found to exhibit activity against MCF-7 cells with an IC $_{50}$ value of $1.8 \mathrm{mg} / \mathrm{mL}$ after $24 \mathrm{~h}$ which is higher value than that of $Z$ ls extract $\left(\mathrm{IC}_{50}\right.$ less than $0.05 \mathrm{mg} / \mathrm{mL}$ after $24 \mathrm{~h}$ ) [75]. The results of cytotoxic action of Z. jujuba extract indicated a reduction inviability and high potent inhibitory effect toward the proliferation of MCF-7 cells, this effect may be due to cell apoptose [76]. However, the cytotoxicity effect reported from $\mathrm{Zls}$ extracts against $\mathrm{HepG}_{2}$ cells was significantly higher than that reported from mung bean sprouts extracts obtained using maceration method with an $\mathrm{IC}_{50}$ of $14.04 \pm 1.5 \mathrm{mg} / \mathrm{mL}$. This extract also contained polyphenolic compounds [77]. The effective cytotoxicity toward hepatocellular HepG 2 and beast MCF-7 could be related to the presence of the some secondary metabolites, some of them are considered the major class of jujube polyphenols, represented from 89 to $94 \%$ of the total phenolic contents mainly flavan-3-ols such as monomer (as (-)-epicatechin, gallocatechin gallate, and (+)-catechin), dimer (procyanidine B2), and polymeric proanthocyanidins in $Z l s$, which were applicated in the inhibition of cell proliferation in different cancer types [47]. Quercetin-3-O-rutinoside found in other parts of Z. lotus, which represents $50 \%$ of jujube flavonoids offers a plausible explanation of the observed cytotoxicity [74].

The present research data suggests that in some cases the ultrasound extraction can positively influence the extraction yield of TPC, TFC, and TTC, also the antitumor activity against the tested cell lines. This is can be related to the mechanical acoustic effects of ultrasound which causes the rupture of the cell wall allowing mass transfer, and therefore increase the recovery process of TPC but following the sonication time (15.94 $\mathrm{min}$ ), which is a very sensitive parameter in extraction procedure. To the best of our knowledge, no study has as yet been carried out on the effects of ultrasounds on phenolic extracted from $\mathrm{Zls}$ and cytotoxicity toward hepatocellular $\mathrm{HepG}_{2}$ and beast MCF-7 of the studied UAE extract from Zls.

\section{Conclusions}

In this study, the effect of ultrasound on phenolic compounds extracted from jujube seeds based on the BBD model was employed to improve the extraction yield and bioactivities of Zizyphus lotus seeds extract. The optimal conditions of UAE were determined as ethanol concentration $50.16 \%$, 
sonication temperature $29.01{ }^{\circ} \mathrm{C}$, sonication time $15.94 \mathrm{~min}$, and solvent-to-solid ratio $34.1 / 1 \mathrm{~mL} / \mathrm{g}$, giving a maximum TPC yield of $2406.0835 \mathrm{mg} \mathrm{GAE} / 100 \mathrm{~g}$. The Zls extracts exhibited a significant antioxidant effect with both DPPH and FRAP assays, with a high inhibitory effect for AChE and HMGR tests and antiproliferative capacities against MCF-7 than $\mathrm{HepG}_{2}$ cell lines. However, this study proved that application of ultrasound technology was efficient for obtaining maximum yield of bioactive compounds from jujube seeds in a shorter time when compared to traditional method which can be used by exploiting the antioxidant properties (food additives, nutraceuticals, etc.), antiacetylcholinesterase, antihypercholesterolemia, and antiproliferative properties which may be useful in the development of new strategies to treat Alzheimer, hypercholesterolemia diseases, and cancer. Further studies are needed to identify active compounds after purification of extract and evaluate the cytotoxic mechanism of Zls extracts with in vivo models which be enable to production on an industrial scale (food, pharmaceuticals, and cosmetics).

Author Contributions: Writing—original draft (lead); formal analysis (lead); writing—review and editing (equal), F.B. Conceptualization (supporting); review; supervision and editing (equal), M.L.S. Supervision of the optimization study and analysis; software (lead); writing-review, supervision and editing (equal), F.D. Supervision of the biological activities, A.R. supervision of some biological activities; methodology (lead); writing-review and editing (equal), N.K. Supervision of the extraction process; writing-review and editing (equal), H.R. All authors have read and agreed to the published version of the manuscript.

Funding: The Portuguese Foundation for Science and Technology, FCT, through the Research Unit grant UID/MULTI/04046/2019 to BioISI; FCT project PTDC/BIA-BQM/28355/2017; BioISIMassSPEC Facility, are gratefully acknowledged for financial support.

Acknowledgments: The ministry of the higher education and scientific research and the faculty of Natural Sciences, Life, and Earth Sciences, University of Bouira, Algeria.

Conflicts of Interest: The authors declare no conflict of interest. The funders had no role in the design of the study; in the collection, analyses, or interpretation of data; in the writing of the manuscript, or in the decision to publish the results.

\section{References}

1. Cai, Y.; Luo, Q.; Sun, M.; Corke, H. Antioxidant activity and phenolic compounds of 112 traditional Chinese medicinal plants associated with anticancer. Life Sci. 2004, 74, 2157-2184. [CrossRef] [PubMed]

2. Shenvi, S.; Kumar, K.; Hatti, K.S.; Rijesh, K.; Diwakar, L.; Reddy, G.C. Synthesis, anticancer and antioxidant activities of 2, 4, 5-trimethoxy chalcones and analogues from asaronaldehyde: Structure-activity relationship. Eur. J. Med. Chem. 2013, 62, 435-442. [CrossRef] [PubMed]

3. Villarroya, M.; Garcia, A.; Marco, J. New classes of AChE inhibitors with additional pharmacological effects of interest for the treatment of Alzheimer's disease. Curr. Pharm. Des. 2004, 10, 3177-3184. [CrossRef] [PubMed]

4. Mehta, M.; Adem, A.; Sabbagh, M. New acetylcholinesterase inhibitors for Alzheimer's disease. Int. J. Alzheimer's Dis. 2012, 728983. [CrossRef] [PubMed]

5. Rinne, J.O.; Kaasinen, V.; Järvenpää, T.; Någren, K.; Roivainen, A.; Yu, M.; Oikonen, V.; Kurki, T. Brain acetylcholinesterase activity in mild cognitive impairment and early Alzheimer's disease. J. Neurol. Neurosurg. Psychiatry 2003, 74, 113-115. [CrossRef]

6. Gašperšič, R.; Koritnik, B.; Črne-Finderle, N.; Sketelj, J. Acetylcholinesterase in the neuromuscular junction. Chem. Biol. Interact. 1999, 119, 301-308. [CrossRef]

7. Martinez, A.; Castro, A. Novel cholinesterase inhibitors as future effective drugs for the treatment of Alzheimer's disease. Expert Opin. Investig. Drugs 2006, 15, 1-12. [CrossRef]

8. Türkan, F.; Atalar, M.N.; Aras, A.; Gülçin, İ.; Bursal, E. ICP-MS and HPLC analyses, enzyme inhibition and antioxidant potential of Achillea schischkinii Sosn. Bioorganic Chem. 2020, 94, 103333. [CrossRef]

9. Harraz, F.M.; Hammoda, H.M.; El-Hawiet, A.; Radwan, M.M.; Wanas, A.S.; Eid, A.M.; ElSohly, M.A. Chemical constituents, Antibacterial and Acetylcholine esterase inhibitory activity of Cupressus macrocarpa leaves. Nat. Prod. Res. 2020, 34, 816-822. [CrossRef]

10. Ressaissi, A.; Attia, N.; Falé, P.L.; Pacheco, R.; Victor, B.L.; Machuqueiro, M.; Serralheiro, M.L.M. Isorhamnetin derivatives and piscidic acid for hypercholesterolemia: Cholesterol permeability, HMG-CoA reductase inhibition, and docking studies. Arch. Pharmacal Res. 2017, 40, 1278-1286. [CrossRef] 
11. Habauzit, V.; Morand, C. Evidence for a protective effect of polyphenols-containing foods on cardiovascular health: An update for clinicians. Ther. Adv. Chronic Dis. 2012, 3, 87-106. [CrossRef] [PubMed]

12. Behera, B.C.; Mahadik, N.; Morey, M. Antioxidative and cardiovascular-protective activities of metabolite usnic acid and psoromic acid produced by lichen species Usnea complanata under submerged fermentation. Pharm. Biol. 2012, 50, 968-979. [CrossRef] [PubMed]

13. Leopoldini, M.; Malaj, N.; Toscano, M.; Sindona, G.; Russo, N. On the inhibitor effects of bergamot juice flavonoids binding to the 3-hydroxy-3-methylglutaryl-CoA reductase (HMGR) enzyme. J. Agric. Food Chem. 2010, 58, 10768-10773. [CrossRef] [PubMed]

14. Pham, D.-C.; Nguyen, H.-C.; Nguyen, T.-H.L.; Ho, H.-L.; Trinh, T.-K.; Riyaphan, J.; Weng, C.-F. Optimization of Ultrasound-Assisted Extraction of Flavonoids from Celastrus hindsii Leaves Using Response Surface Methodology and Evaluation of Their Antioxidant and Antitumor Activities. Biomed Res. Int. 2020, 3497107. [CrossRef] [PubMed]

15. Yi, J.; Wang, Z.; Bai, H.; Yu, X.; Jing, J.; Zuo, L. Optimization of purification, identification and evaluation of the in vitro antitumor activity of polyphenols from Pinus koraiensis pinecones. Molecules 2015, 20, 10450-10467. [CrossRef]

16. Huang, W.-Y.; Cai, Y.-Z.; Zhang, Y. Natural phenolic compounds from medicinal herbs and dietary plants: Potential use for cancer prevention. Nutr. Cancer 2009, 62, 1-20. [CrossRef]

17. Brglez Mojzer, E.; Knez Hrnčič, M.; Škerget, M.; Knez, Ž.; Bren, U. Polyphenols: Extraction methods, antioxidative action, bioavailability and anticarcinogenic effects. Molecules 2016, 21, 901. [CrossRef]

18. Lagoa, R.; Silva, J.; Rodrigues, J.R.; Bishayee, A. Advances in phytochemical delivery systems for improved anticancer activity. Biotechnol. Adv. 2020, 38, 107382. [CrossRef]

19. Hammi, K.M.; Jdey, A.; Abdelly, C.; Majdoub, H.; Ksouri, R. Optimization of ultrasound-assisted extraction of antioxidant compounds from Tunisian Zizyphus lotus fruits using response surface methodology. Food Chem. 2015, 184, 80-89. [CrossRef]

20. Chouaibi, M.; Mahfoudhi, N.; Rezig, L.; Donsì, F.; Ferrari, G.; Hamdi, S. Nutritional composition of Zizyphus lotus L. seeds. J. Sci. Food Agric. 2012, 92, 1171-1177. [CrossRef]

21. Abdoul-Azize, S. Potential benefits of jujube (Zizyphus Lotus L.) bioactive compounds for nutrition and health. J. Nutr. Metab. 2016, 1-13. [CrossRef] [PubMed]

22. Chouaibi, M.; Boussaid, A.; Donsì, F.; Ferrari, G.; Hamdi, S. Optimization of the extraction process by response surface methodology of protein isolate from defatted Jujube (Zizyphus lotus L.) seeds. Int. J. Pept. Res. Ther. 2019, 25, 1509-1521. [CrossRef]

23. Marmouzi, I.; Kharbach, M.; El Jemli, M.; Bouyahya, A.; Cherrah, Y.; Bouklouze, A.; Vander Heyden, Y.; Faouzi, M.E.A. Antidiabetic, dermatoprotective, antioxidant and chemical functionalities in Zizyphus lotus leaves and fruits. Ind. Crop. Prod. 2019, 132, 134-139. [CrossRef]

24. El Maaiden, E.; El Kharrassi, Y.; Qarah, N.A.; Essamadi, A.K.; Moustaid, K.; Nasser, B. Genus Ziziphus: A comprehensive review on ethnopharmacological, phytochemical and pharmacological properties. J. Ethnopharmacol. 2020, 259, 112950. [CrossRef] [PubMed]

25. Shin, M.; Lee, B.-M.; Kim, O.; Tran, H.N.K.; Lee, S.; Hwangbo, C.; Min, B.-S.; Lee, J.-H. Triterpenoids from Ziziphus jujuba induce apoptotic cell death in human cancer cells through mitochondrial reactive oxygen species production. Food Funct. 2018, 9, 3895-3905. [CrossRef]

26. Souid, S.; Elsayed, H.E.; Ebrahim, H.Y.; Mohyeldin, M.M.; Siddique, A.B.; Karoui, H.; El Sayed, K.A.; Essafi-Benkhadir, K. 131-Oxophorbine protopheophorbide A from Ziziphus lotus as a novel mesenchymal-epithelial transition factor receptor inhibitory lead for the control of breast tumor growth in vitro and in vivo. Mol. Carcinog. 2018, 57, 1507-1524. [CrossRef]

27. Ghalem, M.; Murtaza, B.; Belarbi, M.; Akhtar Khan, N.; Hichami, A. Antiinflammatory and antioxidant activities of a polyphenol-rich extract from Zizyphus lotus L fruit pulp play a protective role against obesity. J. Food Biochem. 2018, 42, e12689. [CrossRef]

28. Najjaa, H.; Ben Arfa, A.; Elfalleh, W.; Zouari, N.; Neffati, M. Jujube (Zizyphus lotus L.): Benefits and its effects on functional and sensory properties of sponge cake. PLOS ONE 2020, 15, e0227996. [CrossRef]

29. Hani, A.F.; Zaouani, M.; Mimoune, N.; Ainouz, L.; Djellout, B.; Remichi, H.; Boudjellaba, S.; Bouchoucha, A. Evaluation of Anti-inflammatory and Anti-diarrhoeal Activity of Leaf Aqueous Extracts of Zizyphus Lotus (L) in Albino Wistar Rats. Bull. Univ. Agric. Sci. Vet. Med. Cluj-Napoca Vet. Med. 2020, 77, 53-60. [CrossRef] 
30. Dzah, C.S.; Duan, Y.; Zhang, H.; Wen, C.; Zhang, J.; Chen, G.; Ma, H. The effects of ultrasound assisted extraction on yield, antioxidant, anticancer and antimicrobial activity of polyphenol extracts: A review. Food Biosci. 2020, 35, 100547. [CrossRef]

31. Crupi, P.; Dipalmo, T.; Clodoveo, M.L.; Toci, A.T.; Coletta, A. Seedless table grape residues as a source of polyphenols: Comparison and optimization of non-conventional extraction techniques. Eur. Food Res. Technol. 2018, 244, 1091-1100. [CrossRef]

32. Dahmoune, F.; Boulekbache, L.; Moussi, K.; Aoun, O.; Spigno, G.; Madani, K. Valorization of Citrus limon residues for the recovery of antioxidants: Evaluation and optimization of microwave and ultrasound application to solvent extraction. Ind. Crop. Prod. 2013, 50, 77-87. [CrossRef]

33. Ghafar, M.; Prasad, K.N.; Weng, K.K.; Ismail, A. Flavonoid, hesperidine, total phenolic contents and antioxidant activities from Citrus species. Afr. J. Biotechnol. 2010, 9, 326-330.

34. Hagerman, A. The Tannin Handbook; Miami University: Oxford, OH, USA, 2002.

35. Hammi, K.M.; Hammami, M.; Rihouey, C.; Le Cerf, D.; Ksouri, R.; Majdoub, H. Optimization extraction of polysaccharide from Tunisian Zizyphus lotus fruit by response surface methodology: Composition and antioxidant activity. Food Chem. 2016, 212, 476-484. [CrossRef]

36. Falé, P.L.; Ferreira, C.; Rodrigues, A.M.; Cleto, P.; Madeira, P.J.A.; Florecirc, M.H.; Frazatilde, F.N.; Serralheiro, M.L. Antioxidant and anti-acetylcholinesterase activity of commercially available medicinal infusions after in vitro gastrointestinal digestion. J. Med. Plants Res. 2013, 7, 1370-1378.

37. Guedes, L.; Reis, P.B.; Machuqueiro, M.; Ressaissi, A.; Pacheco, R.; Serralheiro, M.L. Bioactivities of Centaurium erythraea (Gentianaceae) Decoctions: Antioxidant Activity, Enzyme Inhibition and Docking Studies. Molecules 2019, 24, 3795. [CrossRef]

38. Goupy, J.; Creighton, L. Introduction aux Plans D'expériences; Dunod Paris: Paris, France, 2006.

39. Ali, A.; Lim, X.Y.; Chong, C.H.; Mah, S.H.; Chua, B.L. Optimization of ultrasound-assisted extraction of natural antioxidants from Piper betle using response surface methodology. LWT 2018, 89, 681-688. [CrossRef]

40. Dahmoune, F.; Spigno, G.; Moussi, K.; Remini, H.; Cherbal, A.; Madani, K. Pistacia lentiscus leaves as a source of phenolic compounds: Microwave-assisted extraction optimized and compared with ultrasound-assisted and conventional solvent extraction. Ind. Crop. Prod. 2014, 61, 31-40. [CrossRef]

41. Esmaeelian, M.; Jahani, M.; Feizy, J.; Einafshar, S. Effects of Ultrasound-Assisted and Direct Solvent Extraction Methods on the Antioxidant and Antibacterial Properties of Saffron (Crocus sativus L.) Corm Extract. Food Anal. Methods 2020, 1-14. [CrossRef]

42. Koley, T.K.; Kaur, C.; Nagal, S.; Walia, S.; Jaggi, S. Antioxidant activity and phenolic content in genotypes of Indian jujube (Zizyphus mauritiana Lamk.). Arab. J. Chem. 2016, 9, S1044-S1052. [CrossRef]

43. Al-Saeedi, A.H.; Al-Ghafri, M.T.H.; Hossain, M.A. Comparative evaluation of total phenols, flavonoids content and antioxidant potential of leaf and fruit extracts of Omani Ziziphus jujuba L. Pac. Sci. Rev. Nat. Sci. Eng. 2016, 18, 78-83. [CrossRef]

44. Noriega-Rodríguez, D.; Soto-Maldonado, C.; Torres-Alarcón, C.; Pastrana-Castro, L.; Weinstein-Oppenheimer, C.; Zúñiga-Hansen, M.E. Valorization of Globe Artichoke (Cynara scolymus) Agro-Industrial Discards, Obtaining an Extract with a Selective Effect on Viability of Cancer Cell Lines. Processes 2020, 8, 715. [CrossRef]

45. Kim, Y.-J.; Son, D.-Y. Antioxidant effects of solvent extracts from the dried jujube (Zizyphus jujube) sarcocarp, seed, and leaf via sonication. Food Sci. Biotechnol. 2011, 20,167-173. [CrossRef]

46. Cosmulescu, S.; Trandafir, I.; Violeta, N.; Achim, G.; Mihai, B.; Iordanescu, O. Variation of bioactive compounds and antioxidant activity of jujube (Ziziphus jujuba) fruits at different stages of ripening. Not. Bot. Horti Agrobot. Cluj-Napoca 2018, 46, 134-137. [CrossRef]

47. Wojdyło, A.; Carbonell-Barrachina, Á.A.; Legua, P.; Hernández, F. Phenolic composition, ascorbic acid content, and antioxidant capacity of Spanish jujube (Ziziphus jujube Mill.) fruits. Food Chem. 2016, 201, 307-314. [CrossRef]

48. Ghazghazi, H.; Aouadhi, C.; Riahi, L.; Maaroufi, A.; Hasnaoui, B. Fatty acids composition of Tunisian Ziziphus lotus L.(Desf.) fruits and variation in biological activities between leaf and fruit extracts. Nat. Prod. Res. 2014, 28, 1106-1110. [CrossRef]

49. Adewusi, E.A.; Steenkamp, V. In vitro screening for acetylcholinesterase inhibition and antioxidant activity of medicinal plants from southern Africa. Asian Pac. J. Trop. Med. 2011, 4, 829-835. [CrossRef] 
50. Choi, S.-H.; Ahn, J.-B.; Kim, H.-J.; Im, N.-K.; Kozukue, N.; Levin, C.E.; Friedman, M. Changes in free amino acid, protein, and flavonoid content in jujube (Ziziphus jujube) fruit during eight stages of growth and antioxidative and cancer cell inhibitory effects by extracts. J. Agric. Food Chem. 2012, 60, 10245-10255. [CrossRef]

51. Wang, C.; Cheng, D.; Cao, J.; Jiang, W. Antioxidant capacity and chemical constituents of Chinese jujube (Ziziphus jujuba Mill.) at different ripening stages. Food Sci. Biotechnol. 2013, 22, 639-644. [CrossRef]

52. Kamiloglu, O.; Ercisli, S.; Sengül, M.; Toplu, C.; Serçe, S. Total phenolics and antioxidant activity of jujube (Zizyphus jujube Mill.) genotypes selected from Turkey. Afr. J. Biotechnol. 2009, 8, 303-307.

53. Li, J.-W.; Fan, L.-P.; Ding, S.-D.; Ding, X.-L. Nutritional composition of five cultivars of Chinese jujube. Food Chem. 2007, 103, 454-460. [CrossRef]

54. Li, J.-W.; Ding, S.-D.; Ding, X.-L. Comparison of antioxidant capacities of extracts from five cultivars of Chinese jujube. Process Biochem. 2005, 40, 3607-3613. [CrossRef]

55. Benhanifia, M.; Mohamed, W.M.; Bellik, Y.; Benbarek, H. Antimicrobial and antioxidant activities of different propolis samples from north-western Algeria. Int. J. Food Sci. Technol. 2013, 48, 2521-2527. [CrossRef]

56. Choi, J.; An, X.; Lee, B.H.; Lee, J.S.; Heo, H.J.; Kim, T.; Ahn, J.-W.; Kim, D.-O. Protective effects of bioactive phenolics from jujube (Ziziphus jujuba) seeds against $\mathrm{H}_{2} \mathrm{O}_{2}$-induced oxidative stress in neuronal PC-12 cells. Food Sci. Biotechnol. 2015, 24, 2219-2227. [CrossRef]

57. Mazhar, F.; Khanum, R.; Ajaib, M.; Jahangir, M. Potent AChE enzyme inhibition activity of Zizyphus oxyphylla: A new source of antioxidant compounds. Pak. J. Pharm. Sci. 2015, 28, 2053-2059. [PubMed]

58. Tlili, H.; Hanen, N.; Arfa, A.B.; Neffati, M.; Boubakri, A.; Buonocore, D.; Dossena, M.; Verri, M.; Doria, E. Biochemical properties and in vitro biological activities of extracts from seven folk medicinal plants growing wild in southern Tunisia. BioRxiv 2019, 10, 551515.

59. André, R.; Guedes, L.; Melo, R.; Ascensão, L.; Pacheco, R.; Vaz, P.D.; Serralheiro, M.L. Effect of Food Preparations on In Vitro Bioactivities and Chemical Components of Fucus vesiculosus. Foods 2020, 9, 955.

60. Llorent-Martínez, E.; Ortega-Barrales, P.; Zengin, G.; Mocan, A.; Simirgiotis, M.; Ceylan, R.; Uysal, S.; Aktumsek, A. Evaluation of antioxidant potential, enzyme inhibition activity and phenolic profile of Lathyrus cicera and Lathyrus digitatus: Potential sources of bioactive compounds for the food industry. Food Chem. Toxicol. 2017, 107, 609-619. [CrossRef]

61. Zengin, G.; Atasagun, B.; Aumeeruddy, M.Z.; Saleem, H.; Mollica, A.; Bahadori, M.B.; Mahomoodally, M.F. Phenolic profiling and in vitro biological properties of two Lamiaceae species (Salvia modesta and Thymus argaeus): A comprehensive evaluation. Ind. Crop. Prod. 2019, 128, 308-314. [CrossRef]

62. Yılmaz, P.K.; Ertaş, A.; Akdeniz, M.; Avc1, M.K.; Kolak, U. Chemical compositions by LC-MS/MS and GC-MS and biological activities of Chenopodium album subsp. album var. microphyllum. Ind. Crop. Prod. 2019, 141, 111755. [CrossRef]

63. Jiang, Y.; Gao, H.; Turdu, G. Traditional Chinese medicinal herbs as potential AChE inhibitors for anti-Alzheimer's disease: A review. Bioorganic Chem. 2017, 75, 50-61. [CrossRef] [PubMed]

64. Fawole, O.; Amoo, S.; Ndhlala, A.; Light, M.; Finnie, J.; Van Staden, J. Anti-inflammatory, anticholinesterase, antioxidant and phytochemical properties of medicinal plants used for pain-related ailments in South Africa. J. Ethnopharmacol. 2010, 127, 235-241. [CrossRef] [PubMed]

65. Gholamhoseinian, A.; Shahouzehi, B.; Sharifi-Far, F. Inhibitory activity of some plant methanol extracts on 3-Hydroxy-3-Methylglutaryl coenzyme a reductase. Int. J. Pharmacol. 2010, 6, 705-711. [CrossRef]

66. Mohebbati, R.; Kamkar-Del, Y.; Shafei, M.N. Effect of ethyl acetate and aqueous fractions of Ziziphus jujuba extract on biochemical and hematological parameters in rat. J. Rep. Pharm. Sci. 2019, 8, 224.

67. Jurgoński, A.; Juśkiewicz, J.; Zduńczyk, Z.; Matusevicius, P.; Kołodziejczyk, K. Polyphenol-rich extract from blackcurrant pomace attenuates the intestinal tract and serum lipid changes induced by a high-fat diet in rabbits. Eur. J. Nutr. 2014, 53, 1603-1613. [CrossRef] [PubMed]

68. Okon, E.; Kukula-Koch, W.; Jarzab, A.; Halasa, M.; Stepulak, A.; Wawruszak, A. Advances in Chemistry and Bioactivity of Magnoflorine and Magnoflorine-Containing Extracts. Int. J. Mol. Sci. 2020, 21, 1330. [CrossRef]

69. Dahiru, D.; Obidoa, O. Effect of aqueous extract of Ziziphus mauritiana leaf on cholesterol and triglyceride levels in serum and liver of rats administered alcohol. Pak. J. Nutr. 2009, 8, 1884-1888. [CrossRef]

70. Islam, B.; Sharma, C.; Adem, A.; Aburawi, E.; Ojha, S. Insight into the mechanism of polyphenols on the activity of HMGR by molecular docking. Drug Des. Dev. Ther. 2015, 9, 4943. 
71. Zern, T.L.; Wood, R.J.; Greene, C.; West, K.L.; Liu, Y.; Aggarwal, D.; Shachter, N.S.; Fernandez, M.L. Grape polyphenols exert a cardioprotective effect in pre-and postmenopausal women by lowering plasma lipids and reducing oxidative stress. J. Nutr. 2005, 135, 1911-1917. [CrossRef] [PubMed]

72. Cuccioloni, M.; Mozzicafreddo, M.; Spina, M.; Tran, C.N.; Falconi, M.; Eleuteri, A.M.; Angeletti, M. Epigallocatechin-3-gallate potently inhibits the in vitro activity of hydroxy-3-methyl-glutaryl-CoA reductase. J. Lipid Res. 2011, 52, 897-907. [CrossRef]

73. Oonsivilai, R.; Ferruzzi, M.; Ningsanond, S. Antioxidant activity and cytotoxicity of Rang Chuet (Thunbergia laurifolia Lindl.) extracts. J. Food Agric. Ind. 2008, 1, 116-128.

74. Rached, W.; Barros, L.; Ziani, B.E.; Bennaceur, M.; Calhelha, R.C.; Heleno, S.A.; Alves, M.J.; Marouf, A.; Ferreira, I.C. HPLC-DAD-ESI-MS/MS screening of phytochemical compounds and the bioactive properties of different plant parts of Zizyphus lotus (L.) Desf. Food Funct. 2019, 10, 5898-5909. [CrossRef] [PubMed]

75. Hoshyar, R.; Mohaghegh, Z.; Torabi, N.; Abolghasemi, A. Antitumor activity of aqueous extract of Ziziphus jujube fruit in breast cancer: An in vitro and in vivo study. Asian Pac. J. Reprod. 2015, 4, 116-122. [CrossRef]

76. Klaab, Z.M.; AlMalki, F.A.; Hassan, A.M. Anticancer Activities of Ziziphus jujuba Extract on Breast Cancer Cells in vitro. Int. J. Pharm. Sci. Rev. Res. 2018, 52, 125-132.

77. Hafidh, R.R.; Abdulamir, A.S.; Bakar, F.A.; Jalilian, F.A.; Abas, F.; Sekawi, Z. Novel molecular, cytotoxical, and immunological study on promising and selective anticancer activity of Mung bean sprouts. BMC Complement. Altern. Med. 2012, 12, 208. [CrossRef]

Publisher's Note: MDPI stays neutral with regard to jurisdictional claims in published maps and institutional affiliations. 